\title{
Bladder Cancer pT3 TNM Finding v6 and
}

v7

National Cancer Institute

\section{Source}

National Cancer Institute. Bladder Cancer pT3 TNM Finding v6 and v7. NCI Thesaurus.

Code C61213.

Bladder cancer with tumor invading the perivesical tissue. (from AJCC 6th and 7th Eds.) 